\title{
Impact of Iron and Steel Slag on Crop Cultivation: A Review
}

\author{
MIR SYEDA YUHANNATUL HUMARIA
}

Kolhan University, Chaibasa.

http://dx.doi.org/10.12944/CWE.9.1.31

(Received: January 30, 2014; Accepted: Feburary 23, 2013)

\begin{abstract}
This review paper addresses the issuesto analyze the impacts of Iron and Steel slag on crop cultivation. The use of steel slag in agriculture produces not only economic but also ecological advantages. The value of silicon (Si) application for rice (Oryzasativa) has been demonstrated when soil soluble $\mathrm{Si}$ is low.Impact of solid waste on crop cultivation depends on the availability and quantity of different constituents like $\mathrm{PH}$, Ammonia, Nitrites, Nitrates, Permanganate Value (PV), Biochemical Oxygen Demand (BOD5 or BOD), Chemical Oxygen Demand (COD), Total Suspended Solids (TSS) and Turbidity, Total Dissolved Solids (TDS) etcpresent in the solid waste.
\end{abstract}

Key words: Iron and Steel slag, Linz-Donawitz converter, silicon, silicate, chlorosis, chelates.

\section{INTRODUCTION}

Slag is generated during iron and crude steel production. Its use in different application, such as in agriculture, reduces landfill slag and preserves natural resources. The main problem concerning the utilization of steel slag in agriculture consists of the possible leaching of heavy metals. The metals uptake by the plants is affected by the soil properties. For example the $\mathrm{Cr}$ and $\mathrm{V}$ contents into potatoes are reduced in soils with higher content of organic matter and with a heavy texture. In addition, the uptake of $\mathrm{Cr}, \mathrm{V}$ and $\mathrm{Cd}$ by potatoes is favoured by low $\mathrm{pH}$.

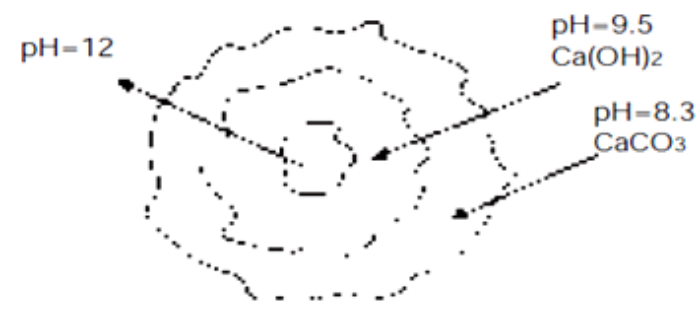

Composition and $\mathrm{pH}$ of a slag particle (Buck 1997)

\section{MATERIALS AND METHOD}

\section{The use of steelmaking slag as fertilisers and as liming agents}

A small amount of slag is used as fertiliser in agriculture and this use depends on the market situations. Due to the low market value of fertilisers, the long distances transportation is a limiting factor. In addition natural lime stone fertilisers are in competition to the slag use. Therefore, the development of new markets for the slag, in order to ensure its utilisation in the future, is required. In this respect the steel industry is committed to minimize the amount of slag which has to be deposited, by improving its use through the increase of its properties (Drissen et al., 200). Until the eighties steel was produced via the ThomasBessemer process, through the open hearth furnaces. The resulting slag containing phosphate has been used as fertiliser for about 70 years.

The current steelmaking process is based on the Basic Oxygen Steelmaking process, where a basic slag is produced in the Linz-Donawitz converter. The LD slag contains about $1-3$ wt $\%$ of $\mathrm{P} 2 \mathrm{O}$, which is too low to be used as phosphate 
fertilizer, but, at the same time, it is too high to be used in the BF or recycled in the sinter plants.

\section{Steelmaking Slag as a Silicon Source for Plant}

After oxygen, silicon ( $\mathrm{Si}$ ) is the most abundant element in the earth's crust. Along with some other elements that are not considered essential, under particular agro-climatic conditions, it can increase the crop yields by promoting some physiological processes. Silicon sources for agricultural purposes must display some important features, such as high soluble Si content, low cost, availability for plants, balanced ratios and amounts of $\mathrm{Ca}$ and $\mathrm{Mg}$, increase of phosphate mobility, suitable physical properties, easy application, and absence of heavy metals.

Because blast furnace slag contains fertilizer components $\mathrm{CaO}, \mathrm{SiO} 2$, and $\mathrm{MgO}$, it is used in rice cultivation as calcium silicate fertilizer. In addition to these three components, steelmaking slag also contains components such as $\mathrm{FeO}, \mathrm{MnO}$, and $\mathrm{P} 2 \mathrm{O} 5$, and is used for a broad range of agricultural purposes, including dry field farming and pastures in addition to rice cultivation. Its alkaline property also remedies soil acidity.

\section{DISCUSSION}

\section{Use of slag as an iron fertilizer}

The problem of iron ( $\mathrm{Fe}$ ) chlorosis can affect many crops on calcareous soils, resulting in substantial yield losses. Generally it has been corrected through the addition of Fe synthetic chelates, but these have resulted very expensive. Various studies have been focused on applying different Fe sources, in order to reduce the economic burden and to recycle some industrial by-products, such as converter slag (Wallace et al., 1982) (Sikka\&Kansal, 1994). They are used not only as soil amendment but also as source of important plant nutrients, such as P, K, Mg and Fe oxides. An

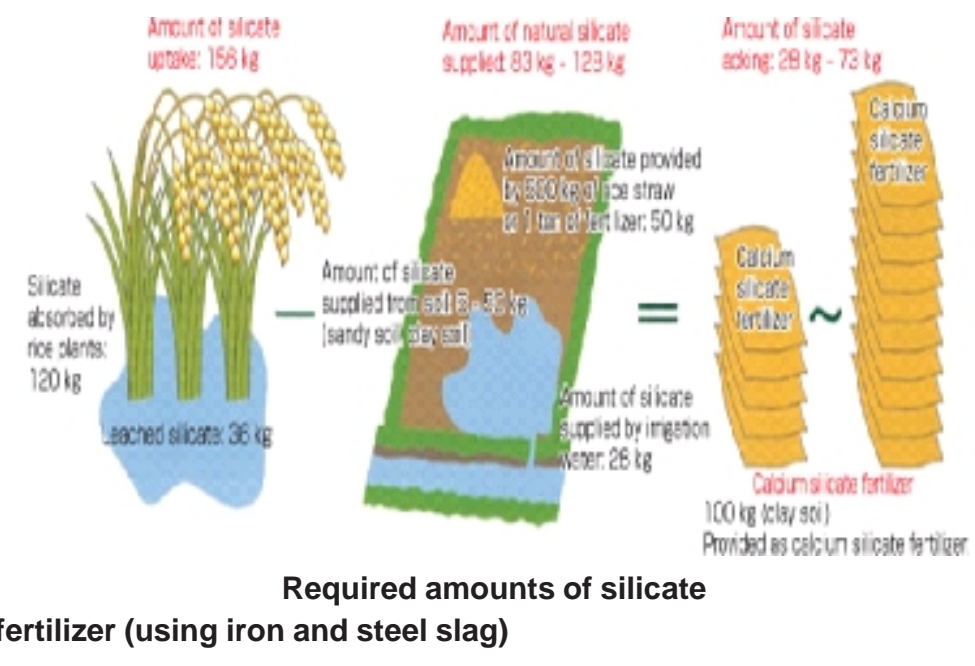

Converter lime fertilizer (using iron and steel slag)

\begin{tabular}{lll}
\hline Wet rice & Iron oxides and manganese give vitality to roots & Fertilizer \\
farming & Silicate, lime, phosphate, and magnesia create healthy rice plants & using \\
& Effective in improving iron-poor soil (preventing root rot, leaf blight, \\
and autumn paddy degradation) & slag \\
Dry field & Creates a general soil fertilizer containing a good balance of & \\
farming & various fertilizer components needed by crops, including silicate, & \\
& iron oxide, lime, magnesia, phosphate, manganese, and boron & \\
& Helps improve acidic and deteriorated soil, creating a well- \\
& balanced soil that not only improves alkalinity but also promotes \\
& the breakdown of organic substances & \\
\hline
\end{tabular}


Calcium silicate fertilizer (using blast furnace slag).

\begin{tabular}{|c|c|c|}
\hline Characteristic & Advantage & Example of use \\
\hline $\begin{array}{l}\text { Silicate for } \\
\text { healthy rice } \\
\text { plants }\end{array}$ & $\begin{array}{l}\text { Promotes photosynthesis by improving light-receiving } \\
\text { condition of leaves. } \\
\text { Boosts root activity, reducing the wilting of lower leaves. } \\
\text { Creates strong stems that resist collapse. } \\
\text { Silicified cells form on leaf surfaces, preventing rice blight. }\end{array}$ & $\begin{array}{l}\text { Fertilizer } \\
\text { using } \\
\text { granulated } \\
\text { slag }\end{array}$ \\
\hline $\begin{array}{l}\text { Boosting dry } \\
\text { matter } \\
\text { production } \\
\text { improving harvest } \\
\text { quantities, } \\
\text { appearance, } \\
\text { and flavour }\end{array}$ & $\begin{array}{l}\text { Boosts dry matter production. } \\
\text { Improves ripening in later growth stages. } \\
\text { (Increases thousand kernel weight.) } \\
\text { increases harvests by increasing the number of unshelled } \\
\text { rice kernels and thousand kernel weight. } \\
\text { Improves appearance quality, increasing the ratio of } \\
\text { highest grade rice. } \\
\text { Promotes ripening to improve flavour. }\end{array}$ & \\
\hline
\end{tabular}

investigation pursued on 1984 showed that the application of a steel by-product (dust containing $430 \mathrm{~g} \mathrm{Fe} \mathrm{kg-1)} \mathrm{as} \mathrm{fertilizer} \mathrm{to} \mathrm{alkaline} \mathrm{soils,} \mathrm{with} \mathrm{or}$ without sulphuric acid, increased dry matter yield of sorghum (Anderson \&Parkpian, 1984). A similar treatment, through a mixture of sulphuric acid and iron sulphates, has allowed to correct Fe chlorosis in corn and alfalfa (Stroehlin\& Berger, 1963).

While converter sludge has been used as Fe fertiliser in calcareous soils with positive results, recently the use of converter slag as source of $\mathrm{Fe}$ fertiliser in some calcareous soils incubation studies has led to relevant achievements. On this subject, pot experiments in a greenhouse have been carried out in China (Wang \&Cai, 2006). Relevant results of this study have shown that the use of moderate steel slag or acidified slag as Fe fertilizer leads to the increase in Fe uptake and corn dry matter yield. This phenomenon is proportional to the application rate and is enhanced by the acidification of slag, although increasing application rates do not produce further improvements in yield and in Fe uptake. This suggests a possible optimized rate of these applied substances. On the other hand, in experiments conducted with the sandy loam dry matter yield significantly decreased. This can be explained because the $\mathrm{Fe}$ availability decreases with salt levels increase, resulting in a yield decrease and an increase of chlorosis in plants. Although further studies still have to be conducted in order to investigate the correct rates of converter slag for different crops and its possible residual environmental impacts to the soil, important results have been achieved by using this by-product as a source of available Fe (Torkashvand, 2011). In an incubation study, by adding to the soil converter slag (from Isfahan steel factory, Isfahan, Iran), containing about $24 \%$ of $\mathrm{Fe}$ oxides, along with elemental sulphur and organic matter, the soil $\mathrm{pH}$ has increased, due to the alkaline $\mathrm{pH}$ of slag. But during the incubation time the $\mathrm{pH}$ decreased. This can be due, according to some previous studies, either to the precipitation of the free carbonates as calcium carbonate (Abassapour et al., 2004) or to the hydrolysis of $\mathrm{Fe} 3+$ in the soil (Rodriguez et al., 1994). The decrease of soil pH probably results from the decomposition of organic matter applied and subsequent organic acids and $\mathrm{CO} 2$ release as well as the buffering ability of the calcareous soils. The observed yield increase in these soils may be due to the some nutrients availability as a consequence of $\mathrm{pH}$ increase.

\section{Use of steel slag for metal stabilization in contaminated soils}

Some investigations about the addition of steel slags in contaminated soils have been carried out. The stabilization technique is based on the incorporation of amendments, in order to minimize metals and metalloids, such as $\mathrm{As}, \mathrm{Cr}, \mathrm{Cu}, \mathrm{Pb}, \mathrm{Cd}$ and $\mathrm{Zn}$ that can be found in contaminated soils at wood treatment plants. In particular, when the copper 
sulphate and chromate copper arsenate are used to protect wood from insects and fungi, they can cause he soil phytotoxicity. While the As can be stabilized by sorption on Fe oxides and also by the formation of amorphous $\mathrm{Fe}$ (III) arsenates, the $\mathrm{Cr}$ immobilization takes place through $\mathrm{Cr}$ eduction from $\mathrm{Cr}(\mathrm{VI})$, which is mobile and toxic, to $\mathrm{Cr}$ (III), which is stable. The Cu stability in soil is $\mathrm{pH}$ dependent, because its mobility increases with decreasing $\mathrm{pH}$. Carbonates, phosphates and clays can reduce the mobility and availability of $\mathrm{Cu}$ in soil. The proposed mechanism consists in precipitation of Cu carbonates and oxy-hydroxides, ion exchange and formation of ternary cation-anion complexes on the surface of $\mathrm{Fe}$ and $\mathrm{Al}$ oxyhydroxides. While $\mathrm{Pb}$ can be stabilized by using phosphorus-containing amendments, that reduce the Pbmobility, $\mathrm{Zn}$ can be immobilized in soil by using phosphorus amendments and clays. To this aim some chemical and mineralogical agents, such as industrial by-products have been applied. For instance, the use of alkaline materials, organic matters, phosphates, alumina-silicates and basic slag has been shown to limit the accumulation of $\mathrm{Cu}$ in plants cultivated in $\mathrm{Cu}$-contaminated soils.

\section{CONCLUSION}

In this review the technical, economical, and environmental aspects of use of iron and steel slag in the field of crop cultivation. The availability nutrient/pollutant in soil depends on the nature of the chemical association between a metal with the organic residual and soil matrix, the $\mathrm{pH}$ value of the soil, the concentration of the element in the compost and the soil, and the ability of the plant to regulate the uptake of a particular element. The value of silicon (Si) application for rice (Oryzasativa) has been demonstrated when soil soluble $\mathrm{Si}$ is low. Slag is most effective used in field of agriculture to condition the soil.Slag is applied to most muck soils and associated sands that are to be planted to rice and sugarcane. There is a need to investigate the availability of silicon in sources which are potentially available for those where response to $\mathrm{Si}$ is also being demonstrated, dry weight. In addition to calcium silicate slag, thermo-phosphate - a fertilizer product that provides $\mathrm{Si}, \mathrm{P}$, and $\mathrm{Mg}$ - appears an excellent source for use.The use of steel slags in agriculture produces not only economic but also ecological advantages.

\section{REFERENCES}

1. www.nationalslag.org/.../nsa_1855_bf_slag_as_agricultural_liming_mat

2. http://www.intechopen.com/books/materialrecycling-trends-and-perspectives/possibleuses-of-steelmaking-slag-in-agriculture-anoverview

3. Aarabi-Karasgani, M., Rashchi, F., Mostoufi, N. \&Vahidi, E. Leaching of vanadium from LD converter slag using sulfuric acid. Hydrometallurgy, 102(1-4), (14-21) (2010), ISSN 0304-386X

4. Ali, M.T. \&Shahram, S.H. Converter slag as a liming agent in the amelioration of acidic soils. International Journal of Agriculture and Biology, 9(5): (715-720) (2007),
5. Peregrina, F.; Mariscal, I.; Ordonez, R.; Gonzalez, P.; Terefe, T.; and Espejo, R Agronomic Implications of Converter Basic Slag as a Magnesium Source on Acid Soils..Soil Science Society of America Journal, 72(2): 402-411. (Mar. 2008-Apr. 2008)

6. Zhang XiangYu; Zhang Hua; He PinJing; Shao LiMing; Wang RuYi; and Chen RongHuanBeneficial reuse of stainless steel slag and its heavy metals pollution risk. Research of Environmental Sciences, 21(4): 33-37. (2008); 